\title{
Childhood Brain Germ Cell Tumor
}

National Cancer Institute

\section{Source}

National Cancer Institute. Childhood Brain Germ Cell Tumor. NCI Thesaurus. Code C5795.

A germ cell tumor arising from brain during childhood. 